\title{
EMBRYONIC AND LARVAL DEVELOPMENT OF JUNDIÁ (Rhamdia quelen, QUOY \& GAIMARD, 1824, PISCES, TELEOSTEI), A SOUTH AMERICAN CATFISH
}

\author{
PEREIRA, C. R. ${ }^{2}$, BARCELLOS, L. J. G. ${ }^{1}$, KREUTZ, L. C. ${ }^{1}$, \\ QUEVEDO, R. M. ${ }^{2}$, RITTER, F. $^{3}$ and SILVA, L. B. ${ }^{2}$ \\ ${ }^{1}$ Faculty of Agronomy and Veterinary Medicine, University of Passo Fundo, Campus I, \\ C. P. 611, Bairro São José, CEP 99001-970, Passo Fundo, RS, Brazil \\ ${ }^{2}$ Laboratory of Aquaculture, University of Passo Fundo, UPF Campus I, \\ C. P. 611, Bairro São José, CEP 99001-970, Passo Fundo, RS, Brazil \\ ${ }^{3}$ Undergraduate student of the University of Passo Fundo, UPF Campus I, \\ C. P. 611, Bairro São José, CEP 99001-970, Passo Fundo, RS, Brazil
}

Correspondence to: Leonardo José Gil Barcellos, Universidade de Passo Fundo, Faculdade de Agronomia e Medicina Veterinária, Campus I, C. P. 611, Bairro São José, CEP 99001-970, Passo Fundo, RS, Brasil, e-mail: lbarcellos@upf.br Received November 10, 2004 - Accepted January, 2005 - Accepted November 1, 2006

(With 2 figures)

\begin{abstract}
The jundiá (Rhamdia quelen, Quoy \& Gaimard) is an endemic South American fish species. Because this species supports cold winters and grows faster during warm months, it has begun to be viewed as an ideal species for fish production in southern South America. In the present study, jundiá oocytes used were obtained by extrusion from females after hormone injection. Soon after hydration, the eggs were transferred to $50 \mathrm{~L}$ conic glass incubators, with constant and controlled water influx. Samples of fertilized eggs were transferred to Petri dishes and, examined under a stereoscopic microscope, were spherical, demersal, and non-adhesive with defined perivitelline space and resistant chorion. Cleavage stages occurred during the first $3.5 \mathrm{~h}$. After hatching, larvae were transferred to $200 \mathrm{~L}$ glass fiber incubators. First signs of embryo movement were observed $21 \mathrm{~h}$ after fertilization; larval eclosion occurred $30.5 \mathrm{~h}$ after fertilization. Present findings may provide a basis for studies aimed at determining the complete ontogeny of jundiá and may be useful in eco-toxicological studies.
\end{abstract}

Keywords: embryonic development, larval development, embryology, Rhamdia, jundiá.

\section{RESUMO}

\section{Estudo do desenvolvimento embrionário e larval do jundiá, Rhamdia quelen, (Quoy \& Gaimard 1824, Pisces Teleostei)}

O jundiá (Rhamdia quelen, Quoy \& Gaimard) é uma espécie endêmica da América do Sul. Por ser adaptada ao frio do inverno e ter um crescimento rápido durante os meses quentes, o jundiá é uma espécie adequada para aqüicultura no sul da América do Sul. Muitos aspectos da fisiologia reprodutiva, larvicultura, hematologia, fisiologia da resposta ao estresse, têm sido recentemente estudados. Os ovócitos utilizados neste estudo foram obtidos pela extrusão de fêmeas após indução hormonal. Logo após a hidratação, foram transferidos para incubadoras cônicas de vidro com capacidade para $50 \mathrm{~L}$, com fluxo de água constante e controlado. Amostras de ovos fertilizados foram colocadas em placas de Petri e examinadas através de estereomicroscópio. Os ovos eram esféricos, demersais e não-adesivos, com espaço perivitelino definido e córion resistente. Os estágios de clivagem ocorreram durante as 3,5 primeiras horas. Após a eclosão, as larvas foram transferidas para incubadoras de fibra de vidro de 2001 . Os primeiros sinais de movimento embrionário foram observados $21 \mathrm{~h}$ após a fertilização, e a eclosão das larvas ocorreu 30,5 h após a 
fertilização. Estes resultados podem servir como base para muitos estudos, objetivando o conhecimento da ontogenia completa do jundiá, e para aplicação em estudos ecotoxicológicos.

Palavras-chave: desenvolvimento embrionário, desenvolvimento larval, embriologia, jundiá, Rhamdia.

\section{INTRODUCTION}

The jundiá (Rhamdia quelen, Quoy \& Gaimard) is an endemic South American fish species that withstands cold winters and presents fast growth rate in summer. These characteristics make jundiá a suitable species for fish production in southern South America or any region with a temperate or subtropical climate. In aquaculture systems, at a density of two to four fish $/ \mathrm{m}^{2}$ jundiá reach a $600-800 \mathrm{~g}$ body weight in eight months (Barcellos et al., 2001b). Our unpublished observations in experimental field trials and at fish farms have shown that this weight is easily reached, but high mortality rates (40-50\%) might occur if small fish (1-3 g) are used to initiate the culture. However, when beginning with heavier juveniles (30-60 g), the final weight will still range from 600 to $800 \mathrm{~g}$, but with mortality rates not exceeding $5-10 \%$. Thus, the more reasonable order in jundiá culture is: hatchery, larviculture (1-6 g), nursery (from 5-6 g to 30-60 g), and termination (from 30-60 g to 600-800 g) (Barcellos et al., 2001b).

A study evaluating the embryonic and larval development of Rhamdia quelen have reported on fish captured in the wild (Ihering \& Azevedo, 1936). However, paremeters related to environmental conditions that could affect embryonic and larval development were not mentioned. However, in recent years several aspects of this species have been investigated, including reproductive physiology (Barcellos et al., 2001b; Barcellos et al., 2002), larviculture (Piaia et al., 1999; Lopes et al., 2001; Townsend \& Baldisserotto, 2001; Townsend et al., 2003), stress response (Barcellos et al., 2001a), hematology (Barcellos et al., 2003, and Barcellos et al., 2004b), physiology (Bello et al., 2000), and transportation (Golombieski et al., 2003). Experiments designed to evaluate jundiá growth, stocking density effects, and cage culture have been performed (Barcellos et al., 2004a) but data on this subject are still scarce.

From the biological standpoint, uncovering each step of embryo and larval development is of great importance. In addition, in these stages most fish species may be more susceptible to changes in dissolved oxygen concentration, $\mathrm{pH}$, salinity, alkalinity, turbidity, and particularly to water contaminants. A complete knowledge of embryo and larval development stages might be useful in studying the effect of even small amounts of water contaminants, mainly those of agricultural origin that eventually reach water springs or ponds used for fish culture, a quite common occurrence in agricultural areas such as those in southern Brazil. In this study, the main objective was to examine the initial stages of embryo and larval development of jundiá under controlled conditions.

\section{MATERIAL AND METHODS}

The present work was carried out at facilities of the University of Passo Fundo, Rio Grande do Sul, southern Brazil (687 m asl), using cultured females and males weighing respectively $685 \pm$ $50 \mathrm{~g}$ and $500 \pm 33 \mathrm{~g}$. After capture, fish were quickly transferred to the laboratory and weighed. Hormonal induction of ovulation was performed using pituitary extract injection according to a routine protocol (Ittzés et al., 1999). The oocytes used were extruded by females within a 9 h 30 min-10 h 55 min period after pituitary extract injection. Extracted oocyte wet weights ranged from $68 \mathrm{~g}$ to $118 \mathrm{~g}$. Following weighing, oocytes were placed in Petry dishes. Collected by abdominal pressure, $10 \mathrm{~mL}$ of mixed semen from three males was added to each batch of eggs and gently mixed in; $100 \mathrm{~mL}$ of water was added to promote sperm activity, and egg fertilization and hydration. Soon after hydration, the eggs were transferred to $50 \mathrm{~L}$ conic glass incubators, with constant and controlled water influx at flow rates of $0.7 \mathrm{~mL} \mathrm{~min}{ }^{-1}$ at a temperature of $24 \pm 1{ }^{\circ} \mathrm{C}$. Depending on the developmental phase, samples of fertilized eggs were taken with a plastic tube at different intervals from the incubators. During the first 2 h 43 min, egg samples were removed at approximately $15 \mathrm{~min}$ intervals, placed in Petri dishes, and examined under a stereoscopic 
microscope (3.2 and $6.4 \mathrm{x}$ magnification) equipped with a digital camera.

After hatching, the larvae of each egg batch were transferred to a $200 \mathrm{~L}$ glass fiber incubator filled with aerated water at an influx rate of 8-10 L $\mathrm{min}^{-1}$. Larval development was analyzed from hatching until the time $(92$ h 45 min after hatching) that they were stocked in a previously fertilized pond (Barcellos et al., 2004).

Water-quality parameters measured in incubation and larviculture were: temperature (at each sampling), dissolved oxygen, alkalinity, $\mathrm{pH}$, turbidity, and total ammonia concentration (colorimetric methods and titulation, before beginning of experiment).

\section{RESULTS}

During embryonic development observation, eggs were kept in glass incubators under moderate agitation by influx at a rate of $180 \mathrm{~L} / \mathrm{h}$ of water having the following characteristics: mean temperature, $24 \pm 1{ }^{\circ} \mathrm{C}$; dissolved oxygen level, $6 \mathrm{mg} \mathrm{L}^{-1}$; alkalinity, $19 \mathrm{mg} \mathrm{L}^{-1}$; $\mathrm{pH}$, 6.8; turbidity, $3 \mathrm{~L}$ NTU; total ammonia concentration $<0.001 \mathrm{mg} \mathrm{L}^{-1}$ that on a $\mathrm{pH}$-temperature conversion table indicated $0.0006 \mathrm{mg} \mathrm{L}^{-1}$ of un-ionized ammonia.

Initial jundiá development of was divided into two phases: embryonic and larval. A sequence of the most important events observed in each phase is shown in Figs 1-2 and Table 1.

Eggs of $R$. quelen were spherical, demersal, and non-adhesive with a clearly defined perivitelline space and resistant chorion. Cleavage stages occurred during the first $3.5 \mathrm{~h}$. First signs of embryo movement were observed $21 \mathrm{~h}$ after fertilization; larval eclosion occurred $30.5 \mathrm{~h}$ after fertilization.

\section{DISCUSSION}

As previously indicated, this study showed that the eggs of Rhamdia quelen were spherical, demersal, and non-adhesive, similar to those described by Godinho et al.(1978) for another fish of the same genus, i.e., Rhamdia hilarii, and for another Siluriform fish, the Pseudoplatystoma coruscans as described by Cardoso et al. (1995).

The perivetelline space in newly fertilized ova of $R$. quelen was relatively smaller than those of other teleosts, e.g., the piabanha (Brycon insignis
Steindachner) (Andrade-Tamelli et al., 2001) and similar to that found by Godinho et al. (1978) for the siluriform Rhamdia hilarii. A larger perivetelline space in some fish species may be understood as an embryo defense against environmental adversities and contributes to higher survival rates in lotic environments (Lake, 1967; Matsuura, 1972). Thus, the characteristics of R.quelen ova fit this species' preferred reproduction sites, which have clear water with little flow (Gomes et al., 2000).

The time required in $R$. quelen to form the first segmentation line in the ovum after fertilization (1 h $15 \mathrm{~min}$ ), was very similar to that previously described for the same species (Ihering \& Azevedo, 1936), similar to that described for Rhamdia sapo (Matkovic et al., 1985), and also to that of Rhamdia hilarii, a silurid species of the genus Rhamdia (Godinho et al., 1978). On the other hand, it was shorter than found for Pimelodella lateristriga, a siluriform fish of the Rhamdia genus (Ihering and Azevedo, 1936).

In the present work, hatching of jundiá eggs occurred $30 \mathrm{~h} 5 \mathrm{~min}$ after fertilization at $24^{\circ} \mathrm{C}$, which is very similar to the period found for $R$. sapo (30 h, 22-24 ${ }^{\circ} \mathrm{C}$; Cussac et al., 1985). In contrast, in the first documented research on embryonic and larval development of jundiá (Ihering and Azevedo, 1936), this period varied from 35 to $46 \mathrm{~h}$ after fertilization at $18-19{ }^{\circ} \mathrm{C}$. In Rhamdia hilarii, the hatching time was $27 \mathrm{~h}$ at $23{ }^{\circ} \mathrm{C}$ (Godinho et al., 1978). The difference in hatching time might be due to environmental conditions like water, temperature, alkalinity, $\mathrm{pH}$ (Cussac et al., 1985), and water flow. In addition, other environmental factors not detected in the water could have affected developmental period of the embryos.

During the period in which larvae were kept in $200 \mathrm{~L}$ glass fiber incubators, a reduction in yolk and a marked evolution in body pigmentation was observed. The fish already had an adult appearance $123 \mathrm{~h} 15 \mathrm{~min}$ after from fertilization, presenting dark coloration and three well-developed pairs of barbels. A similar finding was made by Godinho et al. (1978), who described Rhamdia hilarii with an adult appearance $120 \mathrm{~h}$ after hatching. In Pseudoplatystoma coruscans, an adult appearance was detected four complete days after hatching (Santos \& Godinho, 1994).

In conclusion, the observed eggs of $R$. quelen were spherical, demersal and non-adhesive with a 
TABLE 1

Description of embryonic and larval development stages according to time before and after fertilization and to macroscopic characteristics found in Rhamdia quelen.

\begin{tabular}{|c|c|c|c|}
\hline Stage & Phase & Time after spawning & Observed characteristics \\
\hline & 1 & Immediately after (Fig. 1a) & $\begin{array}{l}\text { Oocyte just spawned; clear yellow coloration and diameter } \\
\text { of } 1.0 \mathrm{~mm} \text {. }\end{array}$ \\
\hline & & $\begin{array}{l}\text { Time following oocyte } \\
\text { fertilization }\end{array}$ & \\
\hline \multirow[t]{23}{*}{ Embryonic } & 2 & $\begin{array}{l}50 \text { min: ovum immediately } \\
\text { after fertilization. (Fig. 1b) }\end{array}$ & $\begin{array}{l}\text { Formation of blastodisc }(830 \mu \mathrm{m}) \text { at the animal pole. Dark } \\
\text { yellow coloration; formation of perivitelline space }(73 \mu \mathrm{m}) \text {. }\end{array}$ \\
\hline & 3 & $1 \mathrm{~h} 15 \min$ (Fig. 1c) & Cleavage stage: first segmentation visible; 2-cell stage. \\
\hline & 4 & $1 \mathrm{~h} 30 \mathrm{~min}$ & Cleavage stage: 4-cell stage. \\
\hline & 5 & 1 h 40 min (Fig. 1d) & Cleavage stage: well-defined 4-cell stage. \\
\hline & 6 & $1 \mathrm{~h} 45 \min$ (Fig. 1e) & Cleavage stage: 8 -cell stage. \\
\hline & 7 & 2 h 15 min (Fig. 1f) & $\begin{array}{l}\text { One pair of divisions, one on each side of 2nd cleavage line; } \\
\text { 16-cell stage. }\end{array}$ \\
\hline & 8 & $2 \mathrm{~h} 27$ min (Fig. 1g) & Cleavage stage: 32 -cell stage. \\
\hline & 9 & $3 \mathrm{~h} 35 \mathrm{~min}$ (Fig. 1h) & Cleavage stage: 64 -cell stage. \\
\hline & 10 & 4 h (Fig. 1i) & $\begin{array}{l}\text { 128-cell stage. Blastomere size diminished; blastoderm } \\
\text { starts to cover yolk in the direction of vegetative pole. }\end{array}$ \\
\hline & 11 & 8 h 5 min (Fig. 1j) & $\begin{array}{l}\text { Blastoderm covers } 2 / 3 \text { of yolk; initiates blastopore formation } \\
\text { begins. }\end{array}$ \\
\hline & 12 & $9 \mathrm{~h} 6 \mathrm{~min}$ & Increasing yolk density. \\
\hline & 13 & 10 h 5 min (Fig. 11) & Blastopore closing forming germination ring. \\
\hline & 14 & 11 h 50 min (Fig. 1m) & Elongation of yolk shape; head and tail growth. \\
\hline & 15 & $12 \mathrm{~h} 50 \mathrm{~min}$ & Vertebral axis development. \\
\hline & 16 & 13 h 50 min (Fig. 2a) & Cephalic organization and differentiation. \\
\hline & 17 & $15 \mathrm{~h} 22 \mathrm{~min}$ & Growth of caudal area. \\
\hline & 18 & 16 h 30 min (Fig. 2b) & Tail development begins. \\
\hline & 19 & $17 \mathrm{~h} 50 \mathrm{~min}$ & Development of the tail. \\
\hline & 20 & 19 h 20 min (Fig. 2c) & Further development of the tail. \\
\hline & 21 & 21 h (Fig. 2d) & $\begin{array}{l}\text { Embryo initiates movement by repeated tail contractions; } \\
\text { round-shaped yolk. }\end{array}$ \\
\hline & 22 & 24 h 50 min (Fig. 2e) & Spontaneous motility. \\
\hline & 23 & $25 \mathrm{~h} 10 \mathrm{~min}$ & Spontaneous motility. \\
\hline & 24 & $26 \mathrm{~h} 20 \mathrm{~min}$ & $\begin{array}{l}\text { Spontaneous motility. Heart beats; visible blood circulation, } \\
\text { although blood is colorless. }\end{array}$ \\
\hline \multirow[t]{5}{*}{ Larval } & 25 & 30 h 30 min (Fig. 2f) & $\begin{array}{l}\text { Hatching. Heartbeats; visible blood circulation. Eye and } \\
\text { yolk pigmentation begins. }\end{array}$ \\
\hline & 26 & 54 h 50 min (Fig. 2g) & $\begin{array}{l}\text { Larva with opened mouth and presenting a pair of barbells; } \\
\text { visible blood circulation; volumetric reduction of yolk } \\
\text { presenting higher pigmentation. }\end{array}$ \\
\hline & 27 & 81 h 50 min (Fig. 2h) & $\begin{array}{l}\text { Larva presenting the three pairs of barbels; pigmentation } \\
\text { beginning in anterior region. }\end{array}$ \\
\hline & 28 & $104 \mathrm{~h} 25 \mathrm{~min}$ & Entire body pigmented. \\
\hline & 29 & 123 h 15 min (Fig. 2i) & Body anatomy similar to that of adult fish. \\
\hline
\end{tabular}



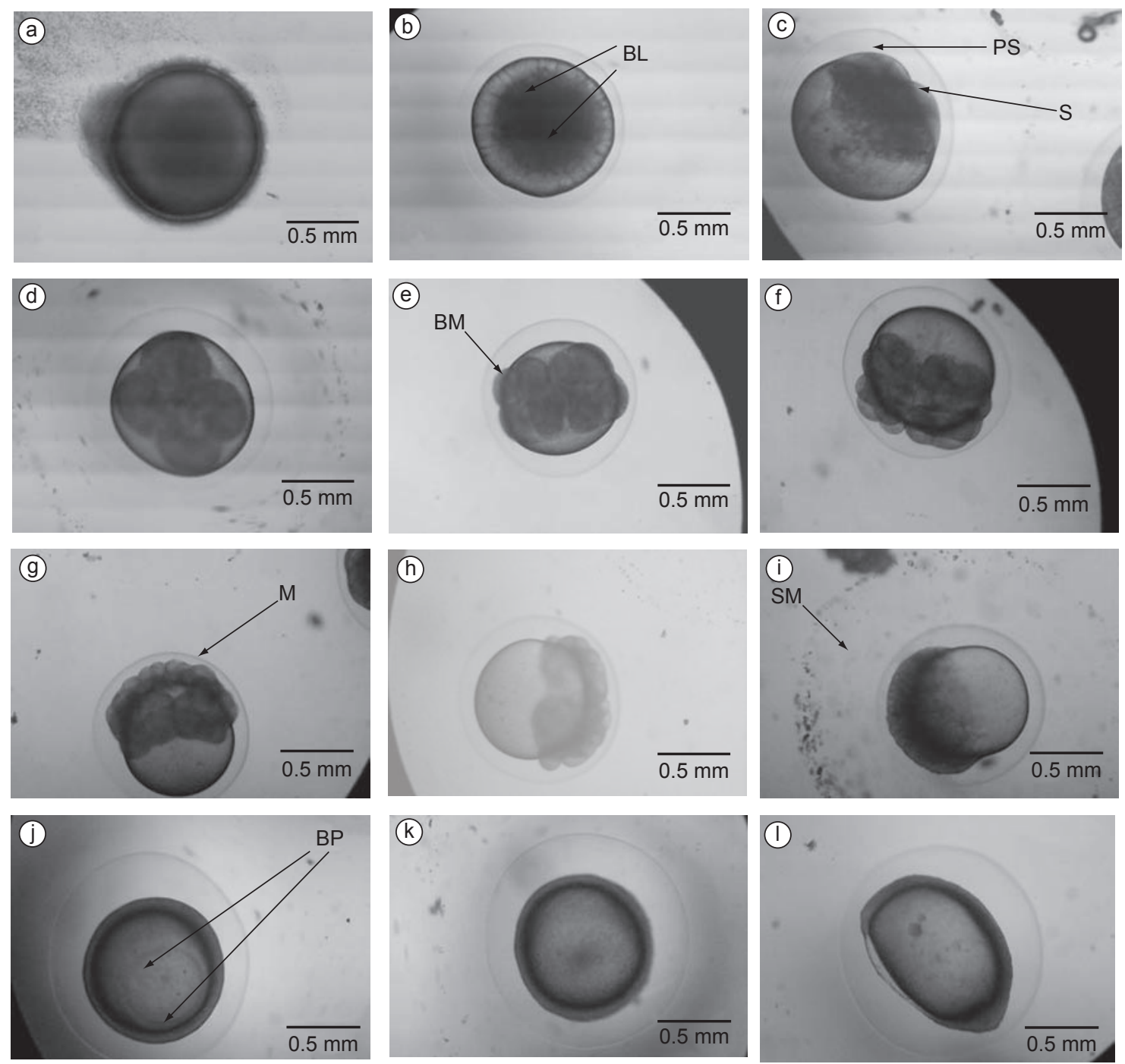

Fig. 1 - Embryonic development of jundiá (Rhamdia quelen): a) just spawned oocyte; b) blastodisc (BLl) formation; c) twocell stage (PS - perivitelline space, S - segmentation line; d) 4-cell stage; e) 8-cell stage (BM - blastomeres); f) 16-cell stage; g) 32-cell stage (M) - ovum membrane; h) 64-cell stage; i) blastoderm covering yolk (SM - secondary membrane, $540 \mu \mathrm{m}$ ); j) blastoderm; blastopore (BP); k) yolk reduction; and 1) yolk conformation change. Magnification 6.4x.

visually defined perivetelline space and resistant chorion. Egg cleavage, embryo movement, and eclosion occurred within the first $30 \mathrm{~h} 5 \mathrm{~min}$ of development. These findings may provide a basis for further studies to determine the complete ontogeny of $R$. quelen and may be useful in studies of water contaminant effects on the development and culture of jundiá, as well as research using this species as an environmental bio-indicator.
Acknowledgments - This work was supported by grants from SCT (Secretaria da Ciência e Tecnologia do Estado do Rio Grande do Sul) and SCI-EMBRAPA 0149/2001/2 (Secretaria de Cooperação Internacional, Empresa Brasileira de Pesquisa Agropecuária). The authors are indebted to Paulo Nadal and Dirceu de Andrada for laboratory assistance, to Mauro Rizzardi, Vilson Klein, Vanderli Rossatto, Claudiomir de Lima for their support at CEPAGRO - University of Passo Fundo, and to Rodrigo Baldissera, Marina Lima, Alexandra Bedin, and Jovani Finco for their competent laboratory work. 

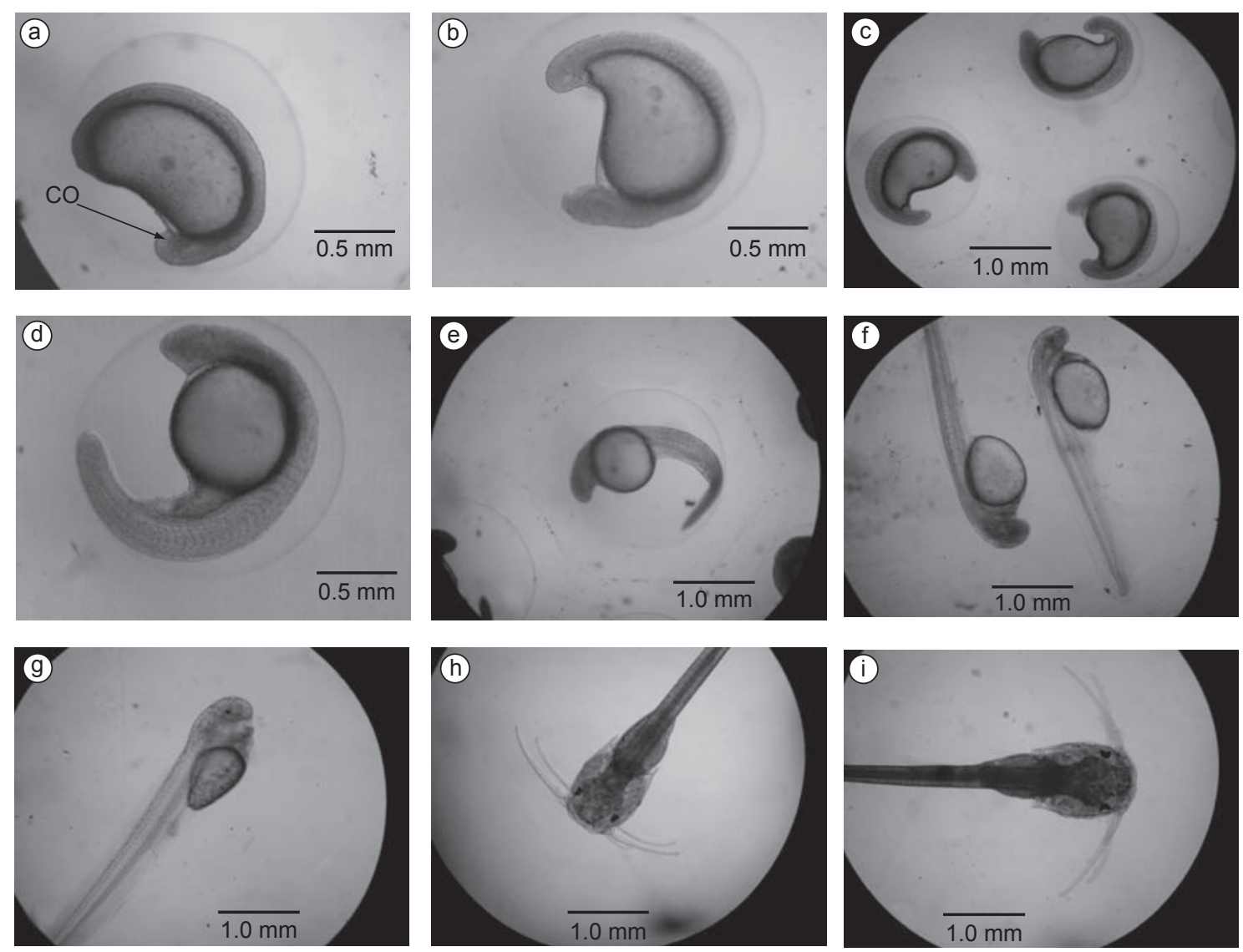

Fig. 2 - a) cephalic organization (CO); b) initiation of caudal development; c) accelerated growth of caudal region and yolk mass diminished; d) movement; e) vigorous movement of the embryo; f) hatching; g) larvae with opened mouth; h) larvae at $4.3 \mathrm{~d}(104 \mathrm{~h})$; and i) larvae at $5.125 \mathrm{~d}(123 \mathrm{~h})$. Magnification of 3.2 and $6.4 \mathrm{X}$.

\section{REFERENCES}

ANDRADE-TALMELLI, E. F., KAVAMOTO, E. T., ROMAGOSA, E. \& FENERICH-VERANI, N., 2001, Embryonic and larval development of the "piabanha", Brycon insignis, steindachner, 1876 (Pisces, Characidae). Bol. Inst. Pesca, 27(1), 21-28.

BARCELLOS, L. J. G., WOEHL, V. M., WASSERMANN, G. F., KRIEGER, M. H., QUEVEDO, R. M. \& LULHIER, F., 2001a, Plasma levels of cortisol and glucose in response to capture and tank transference in Rhamdia quelen (Quoy \& Gaimard), a South American Catfish. Aqua. Res. 32(3): 123-125.

BARCELLOS, L. J. G., WASSERMANN, G. F., SCOTT, A. P., WOEHL, V. M., QUEVEDO, R. M., ITTZÉS, I., KRIEGER, M. H. \& LULHIER, F., 2001b, Steroid profiles in cultured female jundiá, the Siluridae Rhamdia quelen (Quoy and Gaimard, Pisces Telesostei), during the first reproductive cycle. Gen.Comp. Endocrinol,, 121: 325-332.

BARCELLOS, L. J. G., WASSERMANN, G. F., SCOTT, A. P., WOEHL, V. M., LULHIER, F., QUEVEDO, R. M., ITTZÉS,
I. \& KRIEGER, M. H., 2002, Plasma steroid concentrations in relation to the reproductive cycle of cultured male Rhamdia quelen. J. Fish Biol., 61(3): 751-763.

BARCELlOS, L. J. G., KREUTZ, L. C., RODRIGUES, L. B., FIOREZE, I., QUEVEDO, R. M., CERICATO, L., CONRAD, J., SOSO, A. B., FAGUNDES, M., LACERDA, L. A. \& TERRA, S., 2003, Haematological and biochemical characteristics of male jundiá (Rhamdia quelen Quoy \& Gaimard pimelodidae): changes after acute stress. Аqua. Res., 34: 1465-1469.

BARCELLOS, L. J. G., KREUTZ, L. C., QUEVEDO, R. M., FIOREZE, I., SOSO, A.B., CERICATO, L., FAGUNDES, M., CONRAD, J., BALDISSERA, R., BRUSCHI, A. \& RITTER, F., 2004a, Nursery rearing of jundiá, Rhamdia quelen (Quoy \& Gaimard) in cages: cage type, stocking density and stress response to confinement. Aquaculture, 232(1-4): 383-394.

BARCELlOS, L. J. G., KREUTZ, L. C., QUEVEDO, R. M., FIOREZE, I., RODRIGUES, L. B., SOSO, A.B., RITTER, F., CONRAD, J., CERICATO, L., FAGUNDES, M., LACERDA, L. A. \& TERRA, S., 2004b, Hematological 
changes in jundiá (Rhamdia quelen Quoy \& Gaimard Pimelodidae) provoked by usual aquaculture practices, with emphasis on immunosupressive effects. Aquaculture, 237(1-4): 229-236.

BELLO, A. R., FORTES, E., BELLO-KLEIN, A., BELLO, A. A., LLESUY, S. F., ROBALDO, R. B. \& BIANCHINI, A., 2000, Lipid peroxidation induced by Clinostomum detruncatum in muscle of the freshwater fish Rhamdia quelen. Dis. Aquat.Organisms, 42(3): 233-236.

CARDOSO, E. L., ALVES, M. S. D., FERREIRA, R. M. A. \& GODINHO, H. P., 1995, Embryogenesis of the neotropical freshwater Siluriforme Pseudoplatystoma coruscans. Aquat. Living Resour., 8: 343-346.

CUSSAC, V. E., MATKOVIC, M. \& MAGGESE, M. C., 1985, Desarrollo embrionario de Rhamdia sapo (Valenciennes, 1840) Eigenmann y Eigenmann, 1888 (Pisces, Pimelodidae) II. Organogénesis media, organogénesis tardia y eclosión. Rev. Bras. Biol., 45(1-2): 149-160.

GODINHO, H. M., FENERICH, N. A. \& NARAHARA, M. Y., 1978, Desenvolvimento embrionário e larval de Rhamdia hilarii (Valenciennes, 1840) (Siluriformes, Pimelodidae). Rev. Bras. Biol., 38(1): 151-156.

GOLOMBIESKI, J. I., SILVA, L. V. F., BALDISSEROTTO, B. \& DA SILVA, J. H. S., 2003, Transport of silver catfish (Rhamdia quelen) fingerlings at different times, load densities, and temperatures. Aquaculture, 216(1-4): 95-102.

GOMES, L. C., GOLOMBIESKI, J. I., REGINA, A., GOMES, C. \& BALDISSEROTO, B., 2000, Biology of Rhamdia quelen (Telesostei, Pimelodidae). Ciência Rural, 30: 179-185.

IHERING, R. VON \& AZEVEDO, P., 1936, A desova e a hypophysação dos peixes. Evolução de dois Nematognathas. Arch. do Inst. Biológico, 7: 107-120.
ITTZÉS, I., QUEVEDO, R. M., BARCELLOS, L. J. G. \& WOEHL, V., 1999, Uso de hipófise de carpa húngara (Cyprinus carpio) na indução à reprodução de fêmeas e machos de jundiá (Rhamdia quelen). Efeito de diferentes faixas de peso. In: Anais da 51 a . Reunião Anual da SBPC, 1999.

LAKE, J. S., 1967, Rearing experiments with species of Australian freshwater fishes. II. Morphogenesis and ontogeny. Aust. J. Mar. Freshwater Res., 18: 155-173.

LOPES, J. M., SILVA, L. V. F. \& BALDISSEROTTO, B., 2001, Survival and growth of silver catfish larvae exposed to different water pH. Aqu. Int., 9(1): 73-80.

MATKOVIC, M., CUSSAC, V. E., CUKIER, M., GUERRERO, G. A. \& MAGGESE, M. C., 1985, Desarrollo embrionario de Rhamdia sapo (Valencieness, 1840) Eigenmann y Eigenmann, 1888 (Pisces, Pimelodidae). I. Segmentación, morfogénesis y organogénesis temprana. Rev. Bras. Biol., 45(1-2): 149-160.

MATSUURA, Y., 1972, Egg development of scaled sardine Harengula pensacolae Goode \& Bean (Pisces Clupeidae). Bol. Ints. Oceanogr., 21: 129-135.

PIAIA, R., TOWNSEND, C. R. \& BALDISSEROTTO, B., 1999, Growth and survival of fingerlings of Silver catfish exposed to different photoperiods. Aqua. Int., 7(3): 201-205.

SANTOS, J. E. \& GODINHO, H. P., 1994, Morfogênese e comportamento larvais do surubim (Pseudoplatystoma coruscans Agassiz, 1829) sob condições experimentais. Arq. Bras. Med. Vet. Zootec., 46(2): 139-147.

TOWNSEND, C. R., SILVA, L. V. F., \& BALDISSEROTTO, B., 2003, Growth and survival of Rhamdia quelen (Siluriformes, Pimelodidae) larvae exposed to different levels of water hardness. Aquaculture, 215: 103-108.

TOWNSEND, C. R. \& BALDISSEROTTO, B., 2001, Survival of silver catfish fingerlings exposed to acute changes of water $\mathrm{pH}$ and hardness. Aqua. Int., 9(5), 413-419. 
